УДК 342.951

\author{
П. С. Покатаєв
}

\title{
САНІТАРНЕ ОЧИЩЕННЯ ТЕРИТОРІЇ НАСЕЛЕНОГО ПУНКТУ: СУЧАСНІ ПРОБЛЕМИ АДМІНІСТРАТИВНО-ПРАВОВОГО РЕГУЛЮВАННЯ
}

На сьогодні система санітарного очищення населених пунктів $€$ недосконалою, адже відсутня координація та взаємодія органів державної виконавчої влади, зокрема державної санітарно-епідеміологічної служби, охорони навколишнього природного середовища та житлово-комунального господарства, щодо здійснення контролю за санітарним станом територій, збирання, видалення, знешкодження й захоронення побутових відходів. Понад 11 млн тонн побутових відходів, накопичення яких значною мірою залежить від погодних умов, ступеня благоустрою житлових будинків, рівня життя населення тощо, захоронюються на 6 тис. полігонів, більшість із яких перевантажені або не відповідають вимогам екологічної безпеки. Частина відходів утилізується на сміттєспалювальних заводах. Послуги з вивезення побутових відходів надаються лише $75 \%$ населення, що призводить щороку до утворення несанкціонованих звалищ [1]. Усі ці проблеми потребують негайного вирішення, що може бути здійснено завдяки вдосконаленню адміністративно-правового регулювання санітарного очищення території населеного пункту.

Питання щодо санітарного очищення території населеного пункту зазвичай були предметом дослідження науковців у сфері біологічних і хімічних наук, будівництва, транспорту. Зокрема, Т.П. Василюк запропонував технологію очищення стічних вод шляхом експериментальних досліджень процесів трансформації забруднень у стоках [2]. О.Б. Таширев вивчав біотехнології очищення промислових стічних вод на основі термодинамічного прогнозування взаємодії мікроорганізмів із металами та радіонуклідами [3]. Л.А. Аблаєва досліджувала питання очищення стічних вод на міських каналізаційних очисних спорудах із використанням бентонітових глин [4].

Г.О. Діренко розробляє технологічні схеми очищення поверхневого стоку урбанізованих територій залежно від потужності споруд, ступеня забрудненості води та необхідної якості очищення з урахуванням закономірностей його формування [5]. Низка науковців присвятили праці питанню очищення вулично-дорожньої мережі. Зокрема, О.С. Фурманенко розробляє комп- 
лексне математичне забезпечення планування режимів очищення дорожніх покриттів та обсягів прибиральних робіт, розраховує потреби в засобах механізації та затрати ручної праці, транспортні збитки на ділянках робіт [6]. О.В. Приймаченко продовжив його дослідження та вдосконалив методи планування режимів очищення покриття та об'ємів прибиральних робіт як із застосуванням ручної праці, так і з використанням засобів механізації на ділянках очищення дорожнього покриття [7]. О.В. Мостепаном запропоновано систематизовані дані можливих діапазонів коливань кількісного вмісту забруднюючих речовин у складі зливових вод із водозбірних міських і позаміських територій, а також промислових підприємств різних галузей економіки в разі відсутності чи наявності системи очищення зливових вод [8].

Справді, усі ці наукові праці мали значний практичний інтерес щодо ïx реалізації. Завдяки цим пропозиціям можна суттєво покращити якість $i$ безпеку стічних вод, що скидаються в земельні та водні об'єкти, сприяти кращому водовідведенню на територіях населених пунктів в умовах урбанізації, підвищити якість дорожнього покриття. Однак правові питання забезпечення санітарного очищення території населеного пункту так і не знайшли свого відображення в жодній розвідці, що зумовлює актуальність подальшого дослідження.

Правову основу осушення території населеного пункту складають Закон України «Про благоустрій населених пунктів», Закон України «Про державний контроль за використанням та охороною земель», Основи законодавства України про охорону здоров'я, Закон України «Про забезпечення санітарного та епідемічного благополуччя населення», Закон України «Про відходи», Закон України «Про оцінку впливу на довкілля», Наказ Міністерства охорони здоров'я України «Про затвердження Державних санітарних норм та правил утримання територій населених місць», Наказ Міністерства охорони здоров'я України «Про затвердження Державних санітарних правил розміщення, улаштування та експлуатації оздоровчих закладів», ДБН Б.2.2-6:2013 «Склад та зміст схеми санітарного очищення населеного пункту» тощо.

Відповідно до ст. 1 Закону України «Про благоустрій населених пунктів» санітарне очищення території є одним з елементів благоустрою населених пунктів. Більше того, санітарне очищення території населеного пункту є обов'язковою умовою утримання його в належному стані [9].

Термін «санітарне очищення територій населених місць» у законодавстві визначається як комплекс планувальних, організаційних, санітарно-технічних та господарських заходів щодо збирання, зберігання, перевезення, оброблення, утилізації, видалення, знешкодження й захоронення побутових відходів, у тому числі небезпечних відходів у їх складі, що утворилися в населених місцях, а також прибирання об'єктів благоустрою з метою запобігання шкідливому впливу факторів середовища життєдіяльності на життя й здоров'я людини та майбутніх поколінь [10].

Під побутовими відходами законодавець розуміє ті, які утворюються в процесі життя й діяльності людини в житлових і нежитлових будинках 
та які можуть бути твердими, великогабаритними, ремонтними, рідкими і використовуються за місцем їх накопичення [11].

Наказ Міністерства охорони здоров'я України «Про затвердження Державних санітарних норм та правил утримання територій населених місць» регулює порядок створення й розташування контейнерних майданчиків, порядок роздільного збирання побутових відходів, відбору вторинної сировини; порядок влаштування, експлуатації, дезінфекції сміттєпроводів; порядок розміщення вигребів; відведення стічних вод, що утворилися в процесі господарсько-побутової, виробничої діяльності, на забудованій території внаслідок випадання атмосферних опадів тощо.

Державними будівельними нормами встановлено обов'язок забудовника обладнати територію підприємств та майданчики для стоянки транспортних засобів пристроями для збирання й відведення стічних вод, що утворюються внаслідок випадання атмосферних опадів, і спорудами з ї очищення. Під час вибору схеми поверхневого водовідведення необхідно враховувати щільність забудови, рельєф території, функціональне призначення, кліматичні умови, загальний рівень благоустрою території [12]. У процесі здійснення проектування поверхневого водовідведення на забудовника покладено обов'язок із забезпечення виконання мінімального обсягу земляних робіт та наявності локальних очисних споруд (задля зменшення шкідливого впливу на поверхневий шар грунту).

На сьогодні є велика кількість спірних питань щодо санітарного очищення території населених пунктів, зокрема, це стосується розміщення вигребів на території присадибної ділянки. I хоча в Наказі Міністерства охорони здоров'я України «Про затвердження Державних санітарних норм та правил утримання територій населених місць» міститься норма, що вказує на порядок вирішення цих спорів, вона має дуже узагальнюючий характер та не вирішує проблему, про що свідчить велика кількість судових скарг.

Відповідно до п. 2.22 Наказу Міністерства охорони здоров'я України «Про затвердження Державних санітарних норм та правил утримання територій населених місць» вигреби повинні бути розташовані на відстані не менше ніж 20 м від меж земельних ділянок навчальних і лікувально-профілактичних закладів, стін житлових та громадських будівель і споруд, майданчиків для відпочинку населення та дитячих ігор.

Проте щодо присадибної ділянки та відстані вигребу від власного житлового будинку власник визначає порядок його розміщення самостійно, однак із додержанням правил добросусідства, які встановлює ст. 103 Земельного кодексу України.

Так, у п. 1 ст. 103 Земельного кодексу України міститься норма, яка зобов'язує власника або землекористувача земельної ділянки обирати способи ї використання відповідно до цільового призначення з найменшим завданням незручностей (задимлення, неприємних запахів, шумового забруднення тощо); саме в цьому полягає зміст добросусідства [13].

Як у судах першої інстанції, так і в порядку апеляційного чи касаційного оскарження рішень досить часто розглядаються справи щодо дотриман- 
ня правил добросусідства, зокрема, стосовно розташування вигрібних ям. I зазвичай рішення приймаються в бік захисту порушених прав сусідів, які страждають від недотримання відстані розташування вигрібних ям від житлового будинку, колодязя тощо. Як правило, рішення суду полягає в зобов'язанні порушника знищити вигрібну каналізаційну яму, що перебуває на його земельні ділянці [14], демонтувати самовільно збудовану вигрібну яму [15].

Останнім часом суттєвий наголос у сфері охорони навколишнього природного середовища робиться на необхідності роздільного збирання побутових відходів, що здійснюється відповідно до затвердженої Наказом Міністерства регіонального розвитку, будівництва та житлово-комунального господарства України Методики роздільного збирання побутових відходів [11]. Роздільне збирання побутових відходів є методом збирання, за яким ресурсоцінні компоненти побутових відходів (папір, скло, пластик, метал тощо) збирають окремо в спеціальні контейнери для подальшого надходження на переробні підприємства. Потрапляючи на сміттєзвалище, усі ці відходи забруднюють навколишнє природне середовище - грунт, повітря, воду, - залишаючись там від декількох років до століть, адже під впливом багатьох природних чинників вони не можуть швидко трансформуватися. Насамперед забруднення довкілля відбувається під впливом отруйної рідини (фільтрату), яка проходить через усе сміттєзвалище та потрапляє до поверхневих і грунтових вод, спричиняючи їх забруднення [16]. Тому виникає необхідність здійснення роздільного збирання побутових відходів із метою їх утилізації на спеціальних підприємствах. Сьогодні в Україні відбувається таке роздільне збирання вже в 642 населених пунктах, проте основною проблемою залишається відсутність культури споживача комунальних послуг щодо розподілу побутових відходів. Незважаючи на наявність спеціальних контейнерів із написами щодо їх призначення для різного виду відходів, споживачі продовжують скидати сміття в єдиний контейнер. I вирішенням такої проблеми залишається виховання культури населення та підняття його мотивації до сортування відходів.

Корисним є досвід інших країн світу із цього приводу. Так, наприклад, у Німеччині, окрім наявності на прибудинковій території різнокольорових контейнерів для сміття з написами щодо їх призначення, щорічно кожен житель країни отримує поштою особливий лист, у якому детально описано порядок викидання побутових відходів, вказано дні, у які буде вивозитись той чи інший тип сміття впродовж наступних 12 місяців. Також існують спеціальні контейнери для скла, батарейок [17]. Запровадження таких превентивних заходів для виховання культури споживача дало б змогу поступово змінити менталітет і виховати звичку сортування побутових відходів.

На сьогодні наявна структура системи санітарного очищення території населених пунктів є недосконалою, адже вона не забезпечує достатній рівень контролю за санітарним станом територій, збиранням, вивезенням, знешкодженням і захороненням побутових відходів. Однією з проблем такого стану залишається відсутність чіткого розмежування повноважень органів державної влади й місцевого самоврядування та суб'єктів господарювання щодо організації заходів поводження з відходами. 
Так, відповідно до ст. 35-1 Закону України «Про відходи» послуги зі збирання й вивезення побутових відходів мають право здійснювати лише юридичні особи, уповноважені на такі дії органом місцевого самоврядування лише на конкурсних засадах [18]. Однак залишається проблема утилізації відходів у сільській місцевості, де на конкурсних засадах визначається особа, яка повинна збирати та вивозити побутові відходи, проте жителі населеного пункту відмовляються заключати договір із виконавцем, мотивуючи свою відмову відсутністю потреби в цьому. Справді, у сільській місцевості є більше можливостей для самостійної утилізації побутових та органічних відходів, що далі можуть бути використані як добриво. Однак можливість щодо безпечної утилізації скла, пакувальної полімерної тари, засобів гігієни, електроніки, будівельних матеріалів відсутня.

Відповідно до п. п. 3, 11 Постанови Кабінету Міністрів України «Про затвердження Правил надання послуг з вивезення побутових відходів» власники або балансоутримувачі житлових будинків, земельних ділянок повинні укласти договір з особою, яка визначена виконавцем послуг із вивезення побутових відходів. Під час укладення договору сторони узгоджують графік надання послуг з огляду на потреби споживача, норми надання послуг та їх якість [19]. На виконавця покладено обов'язок із забезпечення роздільного збирання побутових відходів. Однак первинне сортування все ж має здійснювати споживач послуг, чого він зазвичай не бажає робити 3 багатьох причин.

Аналізуючи досвід Франції, де в сільських місцевостях немає сервісу з утилізації сміття, можна побачити, що держава дозволила створювати спеціальні прийомні пункти, і більшість послуг зі збирання й сортування сміття виконують приватні компанії під керівництвом місцевих органів влади, які оплачують відповідні послуги за рахунок коштів із податку на нерухомість. Проте незаконне викидання сміття та утворення сміттезвалищ фізичною особою карається тюремним ув'язненням терміном до 2 років і штрафом у розмірі від 300 тис. євро (для юридичних осіб) [17]. Тоді як ст. 82 Кодексу України про адміністративні правопорушення за порушення вимог щодо поводження з відходами під час їх збирання, перевезення, зберігання, оброблення, утилізацію, знешкодження, видалення або захоронення передбачає накладення штрафу на громадян від 20 до 80 неоподатковуваних мінімумів доходів громадян (що складає від 340 грн до 1360 грн) і від 50 до 100 неоподатковуваних мінімумів доходів громадян - на посадових осіб, громадян - суб'єктів підприємницької діяльності (що складає від 850 грн до 1700 грн) [20]. Такий підхід законодавця не стримує фізичну чи юридичну особу від здійснення адміністративного правопорушення, і будь-які намагання органів виконавчої влади здійснювати контроль за виконанням законодавства щодо поводження з побутовими відходами не сприятиме зменшенню правопорушень. Тому доцільно розглянути питання щодо збільшення розміру санкціі.

Отже, обов'язок зі збирання й сортування побутових відходів в Україні покладено на приватні компанії, а не на фізичну особу, яка мешкає в сіль- 
ській місцевості та не має ні часу, ні бажання у зв'язку з великою зайнятістю це здійснювати. До того ж відповідно до Постанови Кабінету Міністрів України «Про затвердження Правил надання послуг з вивезення побутових відходів» за ці послуги передбачається справляння відповідної плати, тоді як у Франції ці послуги є складовою частиною податку на нерухомість.

В Україні відповідно до п. 265.1 ст. 265 Податкового кодексу України передбачається справляння податку на майно, який складається з податку на нерухоме майно, відмінне від земельної ділянки, транспортного податку та плати за землю. У пп. 10.1.1 п. 10.1 ст. 10 Податкового кодексу України міститься норма, яка вказує на те, що податок на майно належить до місцевих податків, який місцеві ради повинні обов'язково встановити на власній адміністративно-територіальній одиниці [21]. Отже, в Україні існує можливість компенсувати вартість послуг зі збирання, сортування й перевезення відходів населенню за рахунок податку на нерухоме майно, відмінне від земельної ділянки, який вони повинні сплачувати.

Так, відповідно до абз. 5 п. 1 ст. 91 Бюджетного кодексу України 3 місцевих бюджетів можуть здійснюватися видатки на програми розвитку житлово-комунального господарства та благоустрою населених пунктів. Відповідно до ст. 1 Закону України «Про благоустрій населених пунктів» санітарне очищення є елементом благоустрою населених пунктів. Отже, доцільно передбачити в місцевих бюджетах таку статтю видатків, як збирання, сортування й перевезення відходів населення, що мешкає в сільській місцевості.

Крім того, прийняття відповідних заходів могло б здійснюватись у межах Державної цільової програми розвитку українського села, яка була затверджена в 2013 р. [22]. У цій програмі підкреслювалося, що однією з причин виникнення складної економічної й соціальної ситуації на селі $€$ недостатній рівень державної підтримки облаштування сільських територій. Очікуваними результатами виконання Державної цільової програми розвитку українського села визнано забезпечення комплексного розвитку інженерної інфраструктури сільських територій, що буде здійснюватися також шляхом забезпечення постійного контролю за станом навколишнього природного середовища в сільських населених пунктах і місцях накопичення відходів, удосконалення нормативно-правової бази 3 питань утилізації відходів.

Отже, завдяки аналізу змісту цієї програми можна переконатись у важливості вирішення проблеми утилізації відходів та в необхідності негайного вирішення цієї ситуації. Із цією метою пропонуємо внести зміни до окремих нормативно-правових актів. Зокрема, до ст. 35-1 Закону України «Про відходи» пропонуємо додати пункт такого змісту: «Жителі сіл, селищ зобов'язані укладати договори з юридичною особою, яка визначена виконавием послуг на вивезення побутових відходів та забезпечує роздільне збирання твердих побутових відходів на безоплатній основі».

До Постанови Кабінету Міністрів України «Про затвердження Правил надання послуг з вивезення побутових відходів» пропонуємо додати 
п. 3-1, який варто викласти в такій редакції: «Жителі ciл, селищ зобов'язані укладати договори з юридичною особою, яка визначена виконавцем послуг на вивезення побутових відходів та роздільне збирання твердих побутових відходів».

Останнім часом із метою підвищення ефективності адміністративного управління суспільним розвитком на відповідній території було взято напрям на децентралізацію управління, поштовхом до чого стало схвалення Концепції реформування місцевого самоврядування та територіальної організації влади в Україні. Адже функціонування органів місцевого самоврядування в більшості територіальних громад не забезпечувало створення й підтримку сприятливого життєвого середовища, необхідного для всебічного розвитку людини, ї самореалізації, захисту їі прав, надання населенню органами місцевого самоврядування високоякісних і доступних адміністративних, соціальних та інших послуг [23]. Одним із завдань Концепції реформування місцевого самоврядування та територіальної організації влади в Україні стало надання територіальним громадам права об'єднувати свої майно й ресурси в межах співробітництва територіальних громад для виконання спільних програм і більш ефективного надання публічних послуг населенню суміжних територіальних громад. Для цього необхідно було створити відповідну законодавчу базу для реалізації права територіальних громад на співробітництво, на виконання чого в червні 2014 р. прийнято Закон України «Про співробітництво територіальних громад» [24], а в лютому 2015 р. - Закон України «Про добровільне об'єднання територіальних громад» [25].

Співробітництво сприяє виникненню нових вигод для його суб’ $€ \mathrm{~K}-$ тів, які полягають у створенні ресурсів для надання послуг, недоступних для малих громад, заощадженні витрат під час надання послуг, поліпшенні якості послуг, кращій координації планування майбутнього розвитку, більш ефективній і прозорій політиці розвитку. Співробітництво, з огляду на його форму й організаційну модель, може мати такі економічні ефекти, як спільне використання автопарку, техніки, іншого майна, залучення спеціалізованих кадрів (контроль за дотриманням правил благоустрою, використанням лісових і водних ресурсів тощо) [26]. Об’єднання спільних зусиль дає змогу знайти більш ефективні способи вирішення проблем, у тому числі й у сфері благоустрою населених пунктів. Однак нова форма взаємодії територіальних громад потребує також нових підходів у сфері організації благоустрою населених пунктів, зокрема й щодо поводження з відходами, з урахуванням спільних інтересів уже об’єднаних територіальних громад.

Корисним є міжнародний досвід щодо застосування Моделі координаційного агента для управління потоками побутових відходів. Такий агент наділяється повноваженнями на управління потоками відходів, обрання постачальників послуг та встановлення тарифів для споживачів. Муніципалітет є лише одним із замовників послуг (наприклад, для вивезення сміття з громадських місць, прибирання територій і надання інших послуг 
у межах державного сектора). Він може бути створений муніципалітетом, групою муніципалітетів, управляючою компанією (групою громадян) [27]. Такий координаційний агент мав би можливість координувати взаємодію між територіальними громадами в межах співробітництва, зокрема, з таких питань:

- реалізації спільних проектів у сфері благоустрою населених пунктів, у тому числі щодо поводження з відходами (збирання, зберігання, перевезення, сортування, утилізація, видалення, знешкодження й захоронення побутових відходів);

- утворення суб'єктами співробітництва спільних комунальних підприємств, установ та організацій у сфері благоустрою населених пунктів, у тому числі й щодо поводження з відходами (переробні підприємства, підприємства з прийняття відходів на утилізацію, із сортування та перевезення відходів);

- спільного фінансування суб’єктами співробітництва підприємств, установ та організацій комунальної форми власності в цій сфері.

У результаті дослідження доведено, що наявна структура системи санітарного очищення території населених пунктів $€$ недосконалою, адже вона не забезпечує достатній рівень контролю за санітарним станом територій, збиранням, вивезенням, знешкодженням і захороненням побутових відходів. Залишилась велика кількість спірних питань щодо санітарного очищення території населених пунктів, зокрема, це стосується розміщення вигребів на території присадибної ділянки.

Останнім часом суттєвий наголос у сфері охорони навколишнього природного середовища робиться на необхідності роздільного збирання побутових відходів. Однак, незважаючи на запровадження цього досвіду в багатьох населених пунктах України, споживачі нехтують встановленими нормами. Вирішення цієї проблеми вбачається у вихованні культури населення та піднятті його мотивації до сортування відходів. Задля цього запропоновано скористатися досвідом Німеччини щодо щомісячного нагадування споживачеві шляхом надання особистого листа про порядок викидання побутових відходів.

Невирішеною залишається проблема утилізації відходів у сільській місцевості, де на конкурсних засадах визначається особа, яка повинна збирати й вивозити побутові відходи, проте жителі населеного пункту відмовляються заключати договір із виконавцем, мотивуючи свою відмову відсутністю потреби в цьому. 3 урахуванням досвіду Франції запропоновано внести зміни до ст. 35-1 Закону України «Про відходи» та до Постанови Кабінету Міністрів України «Про затвердження Правил надання послуг з вивезення побутових відходів».

3 огляду на політику підвищення ефективності управління суспільним розвитком та спрямування на децентралізацію управління запропоновано ініціювати створення Моделі координаційного агента для управління потоками побутових відходів на об’єднаних територіальних громадах у межах їх співробітництва. 


\section{Література}

1. Про схвалення Концепції Загальнодержавної програми поводження з відходами на 2013-2020 роки: Розпорядження Кабінету Міністрів України від 3 січня 2013 р. № 22-р / Кабінет Міністрів України. URL: http://zakon5.rada.gov.ua/laws/show/22-2013-p.

2. Василюк Т.П. Біологічне очищення стічних вод різного походження: автореф. дис. ... канд. с.-г. наук: 03.00.16 «Екологія (медичні науки)»; Житомирський нац. агроекол. ун-т. Житомир, 2009. 20 с.

3. Таширев О.Б. Біотехнології очищення промислових стічних вод на основі термодинамічного прогнозування взаємодії мікроорганізмів з металами та радіонуклідами: автореф. дис. ... докт. техн. наук: 03.00.20 «Біотехнологія»; Нац. ун-т харчових технологій МОН України. К., 2005. 33 c.

4. Аблаєва Л.А. Використання бентонітових глин Кудринського родовища для охорони навколишнього середовища: автореф. дис. ... канд. геол. наук: 04.00.19 «Економічна геологія»; Ін-т геохімії навколишнього середовища НАН України. К., 2002. 21 с.

5. Діренко Г.О. Екологічно безпечні технології очищення поверхневого стоку з урбанізованих територій (на прикладі м. Києва): автореф. дис. ... канд. техн. наук: 21.06.01 «Екологічна безпека»; Київський нац. ун-т будівництва і архітектури. К., 2010. 21 с.

6. Фурманенко О.С. Принципи та методи удосконалення технологічного процесу очищення дорожніх покриттів міських територій: автореф. дис. ... канд. техн. наук: 05.23.20 «Містобудування та територіальне планування»; Київський нац. ун-т будівництва і архітектури. К., 1999. 19 с.

7. Приймаченко О.В. Містобудівні принципи і методи утримання вулично-дорожньої мережі міста: автореф. дис. ... канд. техн. наук: 05.23.20 «Містобудування та територіальне планування»; Київський нац. ун-т будівництва і архітектури. К., 2007. 16 с.

8. Мостепан О.В. Оцінка впливу забруднених зливових вод з поверхні автомобільних доріг на навколишнє середовище: автореф. дис. ... канд. техн. наук: 21.06.01 «Екологічна безпека»; Укр. НДІ екологічних проблем. Х., 2004. 20 с.

9. Про благоустрій населених пунктів: Закон України від 6 вересня 2005 р. № 2807-IV / Верховна Рада України. URL: http:/ / zakon3.rada.gov.ua/laws/show/2807-15/page2.

10. Про затвердження Державних санітарних норм та правил утримання територій населених місць: Наказ Міністерства охорони здоров’я України від 17 березня 2011 р. № 145 / Miністерство охорони здоров'я України. URL: http:/ / zakon3.rada.gov.ua/laws/show / z0457-11.

11. Методика роздільного збирання побутових відходів: Наказ Міністерства регіонального розвитку, будівництва та житлово-комунального господарства України від 1 серпня 2011 р. № 133 / Міністерство регіонального розвитку, будівництва та житлово-комунального господарства України. URL: http:/ / zakon2.rada.gov.ua/laws/show/z1157-11.

12. ДБН Б.2.2-5:2011 «Благоустрій територій». URL: https://dnaop.com/html/32602/doc\% D0\%94\% D0\%91\% \%0\%9D_\%D0\%91.2.2-5_2011.

13. Земельний кодекс України: Закон України від 25 жовтня 2001 р. № 2768-III / Верховна Рада України. URL: http:/ / zakon2.rada.gov.ua/laws/show/2768-14

14. Рішення Віньковецького районного суду Хмельницької області (провадження № 2/2202/113/2012) в справі № 2202/418/2012. URL: https://verdictum.ligazakon.net/ document $/ 26824239$

15. Ухвала Вищого спеціалізованого суду України з розгляду цивільних і кримінальних справ від 4 квітня 2016 р. в справі № 6-29147ск15. URL: http://www.reyestr.court.gov.ua/ Review/56974331.

16. Обов'язкового сортування сміття з нового року не буде. URL: http:/ / vikna.if.ua/news/ category/ua/2017/10/16/76717/view.

17. Звіт за результатами дослідження ринків послуг у сфері поводження з побутовими відходами: схвалено Антимонопольним комітетом України від 11 січня 2018 р. протокол № 2. URL: http: / / www.amc.gov.ua / amku/doccatalog/document?id=139186\&schema=main.

18. Про відходи: Закон України від 5 березня 1998 р. № 187/98-ВР / Верховна Рада України. URL: http:/ / zakon2.rada.gov.ua/laws/show / 187 /98-\%D0\%B2\%D1\% 80 / print1509793533482428.

19. Про затвердження Правил надання послуг з вивезення побутових відходів: Постанова Кабінету Міністрів України від 10 грудня 2008 р. № 1070 / Кабінет Міністрів України. URL: http:/ / zakon3.rada.gov.ua/laws/show/1070-2008-\%D0\%BF. 
20. Кодекс України про адміністративні правопорушення: Закон України від 7 грудня 1984 р. № 8073-X / Верховна Рада УPCP. URL: http://zakon2.rada.gov.ua/laws/show/ 80731-10/print1329896557051809.

21. Податковий кодекс України від 2 грудня 2010 р. № 2755-VI (зі змінами та доповненнями) / Верховна Рада України. URL: http: / / zakon2.rada.gov.ua/laws/show/2755-17.

22. Про затвердження Державної цільової програми розвитку українського села на період до 2015 року: Постанова Кабінету Міністрів України від 19 вересня 2007 р. № 1158 / Кабінет Міністрів України. URL: http: / / zakon2.rada.gov.ua/laws/show / 1158-2007-\% D0\%BF/ print 1510148186580469.

23. Про схвалення Концепції реформування місцевого самоврядування та територіальної організації влади в Україні: Розпорядження Кабінету Міністрів України від 1 квітня 2014 р. № 333-p / Кабінет Міністрів України. URL: http://zakon0.rada.gov.ua/laws/show / $333-2014-\% \mathrm{D} 1 \% 80$.

24. Про співробітництво територіальних громад: Закон України від 17 червня 2014 р. № 1508-VII / Верховна Рада України. URL: http:/ / zakon3.rada.gov.ua/laws/show / 1508-18.

25. Про добровільне об’єднання територіальних громад: Закон України від 5 лютого 2015 р. № 157-VIII / Верховна Рада України. URL: http: / / zakon5.rada.gov.ua/laws/show/157-19.

26. Врублевський О.С. Організація співробітництва територіальних громад в Україні: практичний посібник для посадових осіб місцевого самоврядування. K., 2017. URL: http: / / old.decentralization.gov.ua/ pics / attachments / Organizatsiya-spivrobitnitstva-teritorialnihgromad-v-Ukrayini.pdf.

27. Тверді побутові відходи в Україні: потенціал розвитку. Сценарії розвитку галузі поводження $з$ твердими побутовими відходами: матеріал підготовлений Міжнародною фінансовою корпорацією (IFC, Група Світового банку). URL: https://www.ifc.org/wps/wcm/connect/.

\section{Ано т а ц я}

Покатаєв П. С. Санітарне очищення території населеного пункту: сучасні проблеми адміністративно-правового регулювання. - Стаття.

Доведено недосконалість наявної структури системи санітарного очищення території населених пунктів. Встановлено необхідність вирішення проблеми щодо роздільного збирання побутових відходів, запропоновано запровадження досвіду Німеччини щодо виховання культури населення та підняття мотивації до сортування відходів. Виявлено наявну проблему утилізації відходів у сільській місцевості. 3 урахуванням досвіду Франції запропоновано іiі вирішення шляхом внесення змін до ст. 35-1 Закону України «Про відходи» та Постанова Кабінету Міністрів України «Про затвердження правил надання послуг 3 вивезення побутових відходів». 3 огляду на політику підвищення ефективності управління суспільним розвитком і спрямування на децентралізацію управління запропоновано створення Моделі координаційного агента для управління потоками побутових відходів на об'єднаних територіальних громадах у межах їх співробітництва.

Ключові слова: санітарне очищення території, населені пункти, адміністративно-правове регулювання, побутові відходи, благоустрій населених пунктів.

\section{Анн н т а ци я}

Покатаев П. С. Санитарная очистка территории населенных пунктов: современные проблемы административно-правового регулирования. - Статья.

Доказано несовершенство существующей структуры системы санитарной очистки территории населенных пунктов. Установлена необходимость решения проблемы по раздельному сбору бытовых отходов, предложено введение опыта Германии по воспитанию культуры населения и повышению мотивации к сортировке отходов. Выявлена имеющаяся проблема утилизации отходов в сельской местности. С учетом опыта Франции предложено ее решение путем внесения изменений в ст. 35-1 Закона Украины «Об отходах» и Постановление Кабинета Министров Украины «Об утверждении пра- 
вил предоставления услуг по вывозу бытовых отходов». Учитывая политику повышения эффективности управления общественным развитием и направленность на децентрализацию управления, предложено создание Модели координационного агента для управления потоками бытовых отходов на объединенных территориальных общинах в рамках их сотрудничества.

Ключевые слова: санитарная очистка территории, населенные пункты, административно-правовое регулирование, бытовые отходы, благоустройство населенных пунктов.

\section{S u m m a r y}

Pokataiev P. S. Sanitary cleaning of the territory of the placed item: current problems of administrative and legal adjustment. - Article.

The imperfection of the existing structure of the sanitary cleaning system of the territory of settlements is proved. The necessity of solving the problem of separate collection of domestic waste is established, the introduction of Germany's experience in raising the culture of the population and raising the motivation to waste sorting is proposed. The existing problem of utilization of waste in the countryside is revealed. Taking into account the French experience, it was proposed to resolve it by amending the Art. 35-1 of the Law of Ukraine "On Waste" and the Resolution of the Cabinet of Ministers of Ukraine "On Approval of the Rules for the Provision of Services for the Export of Household Waste". Taking into account the policy of improving the efficiency of management of social development and focusing on the decentralization of management, it is proposed to create a Model Coordinating Agent for managing the flows of household waste in the united territorial communities within the framework of their cooperation.

Key words: sanitary clearing of the territory, settlements, administrative and legal regulation, domestic waste, improvement of settlements. 